\title{
CHAPTER 8 \\ PROCESSES OF ECONOMIC GLOBALIZATION AND THEIR EFFECT ON DIVERSIFICATION
}

\section{Korinko M. D.}

\section{INTRODUCTION}

In the current economic development of Ukraine, diversification should be considered in connection with the processes of globalization of the world economy. There have become popular ideas on the need for concentration of efforts in key areas of economic activity. The reason for this has become the processes of spreading the factors of the geographical and financial impact on the state of production and the desire of product manufacturers to reduce costs, using the effect of the economy on the scale of production. This is exactly what determines the fact that enterprises define their areas of activity focusing on key business areas that are in line with the state of development of globalization processes.

The current stage in the development of international business is characterized by profound changes throughout its system. Its essential feature is globalization, which involves strengthening the interdependence and mutual influence of different areas of international business. Globalization processes predetermine the state where no phenomenon in a society, regardless of its nature, either economic, political or legal, cannot be considered in isolation from others.

Globalization of the economy introduces changes to traditional views on the quality of goods and services, their level of production costs, productivity, production time, etc. This forces the founders and senior executives to develop draft decisions on changes in the business of companies, adapting it to new conditions and creating new competitive advantages. Competition between companies is more often more acute than it is at the national level as fundamentally different methods of competition are used. Most companies were originally engaged in only one industry, one business area. Even if they did not avoid the diversification process in other sectors, a significant part of the income from their activities continues to flow from the previously developed industry. Diversification is a promising strategy in the 
situation when the company exhausts all the opportunities for further growth in its business (including any integration opportunities to strengthen its competitive position).

\subsection{Globalization processes in the development of international entrepreneurship}

The most important factor determining the further development of the world economy of the modern period is the globalization of the world economy. It is based on the growing interdependence of national economies and their closer integration. The process of globalization covers not only the level of interstate relations but all levels of the economy.

Primarily globalization is considered to be an important source of new opportunities; on the other hand, it is the cause of many troubles and even conflicts within individual states, as well as between countries (regions). It is expedient to assess globalization as the highest stage of internationalization. In the broader context, it should mean a combination of processes and phenomena such as cross-border flows of goods, services, capital, technology, information, and cross-border movement of people, predominant orientation in the world market in trade, investment and other transactions (at the level of companies), territorial and institutional integration of markets, as well as the emergence of global problems in terms of environmental degradation or excessive population growth, for which global cooperation is required. A characteristic feature of globalization is the existence of international flows, which under liberalization conditions are almost or completely not controlled by national legislation. Basically, these are the streams of capital and information. Globalization originates from the process of internationalization, which, from the standpoint of individual countries develops in two directions - inward and outward. Inward development means that the process goes through the expansion of the use of foreign goods, capital, services, technology, and information in the sphere of domestic consumption of this country. Outward development is characterized by the predominance of the country's orientation to the world market and the global expansion of companies in trade, investment, and other transactions. The main consequence of this process along with the growing interdependence of states is the spatial and institutional integration of markets, which stimulated economic progress. 
According to a more in-depth analysis of the current definitions of this term, three main general methodological approaches are identified. Within the framework of the first approach, globalization is considered as a modern manifestation of processes of internationalization deepened and modified under the influence of the technological and innovation component of international business. This approach in the relevant definitions is presented by N. Dumnaia ${ }^{1}$, A. Nekipelov ${ }^{2}$, I. Osadchaia ${ }^{3}$. The similar approach is presented in the Ukrainian economic encyclopaedia as follows "Globalization is a category that reflects the process of exchange of goods, services, capital, and labour force that extends beyond the borders of the state and from the 60s of the twentieth century acquires the forms of constant and steady growing interstate binding of national economies"4.

Such a theoretical approach to the interpretation of globalization actually brings it to the next evolutionary stage of the development of internationalization in the world economy. The presence of another definition largely determines the need for other approaches to the interpretation of the phenomenon of globalization rather than reducing its evolutionary forms to reflection using a different category. That is why most economists do not share the idea of the evolutionary succession of globalization of internationalization processes. Such succession may have a chronological character while at the substantive level it may differ from the phenomenon - the chronological predecessor, even if its precondition represents the most complete and vivid forms. For example, E. Kochetov introduces another intermediate stage between multinationalization and internationalization - mondialization. Accordingly, internationalization presupposes the presence of relatively isolated national economies linked to each other through the world market. Mondialization provides the integrity of the world economy on the basis of integration-reproductive links, whereas globalization, in his opinion, is "not so much as the strengthening of economic interrelations and interpenetrations as the creation of economic relations that ensure

\footnotetext{
${ }^{1}$ Думная Н. Глобальная экономика - новая среда международного бизнеса. Интернационализаџия и глобализация на бизнеса. Свищов, 1998. С. 2-16.

2 Некипелов А. Обзор: Глобализация как вызов национальным экономикам. Понятие глобализации. Свободная мыслль. 1999. №1. С. 117.

3 Осадчая И. Глобализация и государство: новое в регулировании экономики развитых стран. МЭиМО. 2002. №11. С. 3-14.

4 Глобалізація / Економічна енциклопедія: У трьох томах. Т. 1. Київ : Видавничий центр «Академія». 2000. С. 264-265.
} 
survival and development in the context of the evolution of man and nature"5. S. Moiseyev and K. Mikhailenko raise the issue to a more restricted verification framework for economic analysis, arguing that "the term 'internationalization' largely reflects the situation when operations in foreign markets are increasing while 'globalization' means more and more integration of national economies, including financial markets, which ultimately leads to the creation of a single market"6.

Formation of the unity of the world in the process of globalization, through which the world economy acquires completed holistic forms, is the methodological basis of alternative approaches to the interpretation of globalization. They rely on a broader conceptual vision of globalization processes that creates the preconditions for convergence and homogeneity of societies, countries, cultures, world outlook, etc. For example, V. Havel defines globalization as "a process that reduces diversity", W. Anderson regards globalization as "the flow of forces that provide convergence that creates a real single world"

Convergence and rapprochement by extrapolation to the epistemological contours of economic discourse are divided into two aspects, each of which is represented by appropriate approaches. According to one of them, globalization is considered in the context of increasing interdependence and interpenetration, diffusion of economic systems, and integration at the micro and macro levels. From this very angle, globalization is considered by the experts of the International Monetary Fund ${ }^{9}$. The mentioned is supported by A. Filippenko who defines globalization as "a postmodern product, a transition from an industrial to a post-industrial stage of economic development," from which it reveals the signs of this process, emphasizing the growing "interdependence of the economies of different countries, increasing the integrity and unity of the world economy..."10 J. Stiglitz notes the integration-convergence nature of globalization. He argues that

\footnotetext{
${ }^{5}$ Кочетов Э. Геоэкономика. Москва : БЕК. 1999. 480 с.

6 Моисеев С. Михайленко К. Terra Incognita: глобализация финансовых рынков. Bonpocbl экономики. 1999. №6. С. 123-135.

7 Что требует осмысления в процессе глобализации. Резюме выступления президента Чехии Вацлава Гавела, а также результаты обсуждения, состоявшегося на конференции в Университете штата Мичиган. Трансформачия. 2000. Август-сентябрь. С. 4.

${ }^{8}$ Anderson W. All Connected Now. Life in the First Global Civilization. N.Y.: Westview Press. 2001. $320 \mathrm{p}$.

${ }^{9}$ World Economic Outlook. Wash. (D.C.): IMF. 1997. P. 44-48.

${ }^{10}$ Глобалізація економічних процесів. Світова економіка : Підручник / А.С. Філіпенко, О.І. Рогач, О.І. Шнирков та ін. Київ : Либідь, 2000. С. 51-66.
} 
globalization is "ever closer integration of countries and peoples generated by a gigantic decline in transport and communications costs and the removal of artificial barriers to the movement of goods, services, capital, knowledge, and to a lesser extent people across national borders"11.

Within the framework of this conceptual direction but with some difference in emphasis, the third approach to the definition of globalization is based on the fact of convergence and integration of markets. Without neglecting the fundamental essential and integrative principle of globalization, Ch. Hill also focuses on the primacy of market integration into a holistic system: "...we call the process of globalization a move towards a more integrated and interconnected world economy. This process has two main components: the globalization of markets and the globalization of production. The globalization of markets is the process of uniting historically separate and distinct national markets into one large market space" ${ }^{\prime 2}$. G. Kolodko states that globalization lies in "the creation of a single world-wide capital market type" or "is the process of creating a liberalized and integrated world market of goods and capital, as well as the formation of a new international institutional system that serves the development of production, trade, and financial flows in worldwide scale" $" 13$.

Concerning two interpretative trends, which emphasize either the growth (strengthening) of the interdependence of national economies, or the formation of a single market as a result of their integration and association, it can be argued that these processes reflect particular aspects of one phenomenon and cannot claim the role of defining selfsufficiency. Thus, the integration of markets that are geographically and historically united in one economic and practical space reflects the aspect of the formation of holistic business communication networks, which, of course, do not take into account fragmentation of such space by affiliation to a separate political state. This very idea reflects the fact that as a result of such integration, the interdependence of individual states and separate sectors of national economies increases, as the formation of their elements and components at the micro level takes place on a cross-cutting basis and under the influence of the ongoing market-based allocation processes. Accordingly, it is these aspects in

\footnotetext{
${ }^{11}$ Stiglitz J. Globalization and Its Discontents. N.Y.: W.W. Norton\&Co, 2002. 300 p.

${ }^{12}$ Гіл Ч. Міжнародний бізнес. Київ : Основи, 2001. 854 с.

${ }^{13}$ Колодко Гж. Глобалізація і перспективи розвитку постсоціалістичних країн. Київ : Основні цінності, 2002. 248 с.
} 
their totality should serve as a reference point for the verification of globalization processes.

Economists P. Hirst and G. Thomson argue that globalization is fundamentally different from the phenomenon of internationalization; it should be understood as "the formation of a new economic structure and not only as a conjuncture shift towards the intensification of international trade and investment within the existing system of economic relations"14.

In general, this trend is not new: the process, which was previously taken to be called "internationalization of economic life", has been going on for decades. It is difficult to disagree with this, but at the same time, in recent years, the accumulated quantitative changes have led to a qualitative leap, to a new status of economic life in general, new content for such seemingly self-evident, established concept as the "world economy". The undeniable fact is that there have taken place qualitative changes in the structure and dynamics of the world economy since the 90s. The 20th century is the growth of the openness of national economies, which is bordered by the erosion of national borders, which has led to more accelerated growth in the world trade and investment; the emergence of global standards of production, consumption, trade, and finance. On the other hand, globalization is not an objectively determined and uncontrolled process, in any case, not so much that national governments and countries could not consciously find their place in the global economy.

Transnationalization is an important component of the internationalization process and one of the main sources of globalization, within which a certain share of production, consumption, export, import, and income of the country depends on the decisions of international centres outside the country. The process of globalization of the economy has accelerated in recent decades when different markets, in particular, capital, technology, and goods, and to a certain extent, labour, are becoming increasingly interconnected and integrated into a multilayer network, creating new connections in production, product development, design, commodity universalisation, and marketing. The main area of globalization is the international economic system (world economy), that is global production, exchange, and consumption, carried out by enterprises within national economies and in the world market. The international economic system has grown into a complex structure that

\footnotetext{
${ }^{14}$ Герст П., Томсон Г. Сумніви в глобалізації. Пер. з англ. Київ : К.І.С., 2002. 306 с.
} 
has about 200 political units, including 187 states. All of them are, to some extent, involved in the production of the aggregate product and are trying to build and regulate their national markets. This is due to an extremely difficult situation in terms of the internationalization process, and not only in connection with the emergence of new political and economic centres involved in decision-making. New industries based on modern technologies have created the need for designing relevant international structures. The scientific and technological progress that underlies technological change is by its nature an international process.

Production and consumption in many countries depend decisively on whether they can provide the import of raw materials and energy carries. A number of countries in support of their economic growth are in urgent need of the import of capital and consumer goods and sometimes of skilled labour. Such international interconnections necessitate the intensification of financial flows and services, the network of international freight transportation and communications.

The result of deepening the internationalization process is the interdependence and interaction of national economies. It can be perceived and interpreted as the integration of states into a structure close to a single international economic system. Although the bulk of the global product is consumed in producing countries, national development is increasingly aligned with global structures and is becoming multi-faceted and diverse.

The modern world is developing towards a global economy in which goods, services, financial capital, people, information, knowledge, ideas freely overcome the geographical boundaries of states. There are essentially new essences (such as the global market, global company) and phenomena (global competition, global cooperation, etc.). The global economy is a completely different way of global economic management, based on the subordination of both domestic and international economic processes to unified laws.

A comprehensive analysis of world trends in the global market for services in the conditions of globalization, transnationalization, and regionalization, conducted by G.O. Voroshilova, provided an opportunity to identify topical issues of globalization and its impact on the development of the world market for services ${ }^{15}$.

\footnotetext{
15 Ворошилова Г. О. Концептуальні засади дослідження глобалізації та іiі впливу на розвиток світового ринку послуг. Глобальні та національні проблеми економіки. 2017. №16. C. 38-42. URL: http://global-national.in.ua/archive/16-2017/16_2017.pdf
} 
Globalization processes are connected with a qualitatively new era in the development of international entrepreneurship. The technological gap, income gap, and inequality between regions, countries and in the midst of countries are increasing. This suggests that further integration of the world economy will continue, but this process will remain rigid in terms of competition, asymmetric in terms of inequality between winners and losers.

Analysis of the problematic aspects and positive effects of globalization and integration processes on the Ukrainian economy was made by N.O. Botvyna. It is determined that globalization touches on all the aspects of the socio-economic life of practically all countries of the world and that this process is objective and irreversible ${ }^{16}$.

International activity is expanding through the acquisition or creation of new companies, organization of joint ventures or entering into other types of associations. For international, by the nature of corporations, the most typical concentration is the kind of economic activity that is associated with international exchange. The growth of exports is the result of deepening of specialization, which in turn contributes to an increase in production volumes. In economic theory, the link between the development of export specialization and the country's economic growth is characterized by the following: an increase in exports by $1 \%$ leads to a $0.1 \%$ increase in the Gross Domestic Product. The structure of the industry is characterized by such categories as the number and size of companies, the degree of product diversification, barriers to penetration into the industry. When it comes to international industries, an important parameter is the degree of internationalization of companies that comprise it.

The globalization of the economy forces companies to completely determine their development strategy in a new way. It becomes increasingly difficult to divide the strategy into internal and external, competitive and structural. Goods and services are produced as a result of the transformation of capital, which at the same time has material and monetary, labour and intellectual forms. The presence of all these forms of capital at the disposal of the company is a prerequisite for its business activity.

\footnotetext{
${ }^{16}$ Ботвіна Н. О. Вплив глобалізаційних та інтеграційних процесів на економічну безпеку України. Еконолічний аналіз: зб. наук. праць. Тернопіль : Видавничо-поліграфічний центр ТНЕУ «Економічна думка», 2014. Том 16. № 1. С. 28-33. URL: https//www.econa.org.ua/index/econa/article/.../pdf_35.
} 
Monetary and material capital has become relatively more affordable, despite the reduction in the share of savings in industrialized countries. In the modern world, there is no competition, and cooperation of companies becomes the basis of their business success and prosperity. Cooperation and collaboration give companies immeasurably more significant strategic competitive advantages than the competition itself. Just like the war, it is probably the most competitive of all conceivable forms of behaviour, and its success most often depends on participating in the right alliance.

The economy of the modern period of development of society, in which the strategic positions of business increasingly depend on its cooperative ties in the business environment, makes the managers constantly ask themselves: who can I unite with, how I can unite with those, who share my interests and goals to achieve our common goals? Managers can make their companies more competitive by creating coalitions with those who share common interests with workers, managers, suppliers, buyers, and even fierce rivals.

The study provided an opportunity to highlight at least three reasons why cooperation in the modern world becomes more important for business success than the competition.

Cause 1 is the globalization of the economy. In a globalized world, it is strategically more important for any business to be a part of the world (global) economic system than to oppose it. Becoming a part of the global economic system (this can only be achieved through cooperation and collaboration, and in no way through competition), the business will develop synchronously with the world economy.

Cause 2 deals with intellectualization of business. Production of goods and services is increasingly in need of the use of intellectual capital - knowledge. Products and services are becoming more complex and require the use of a portfolio of well-known technologies for their production. This, in turn, is possible only as a result of cooperation, and not as a result of struggle and confrontation in the market.

Cause 3 denotes that the depth of specialization in society has reached the level at which the appearance of the final product or service is possible only if all members of the value chain are interested in it. If in the early stages of the development of industrial production, the value chain was essentially double-sided (supplier and manufacturer), and ready for sale in the market, the cost appeared from the manufacturer, in 
the modern world the number of such links is much larger, and thus it is practically impossible to distinguish the main one.

According to the results of the study, it is worthwhile to note that the global trend of the world economic development is the globalization of the world economy, the basis of which is the growth and complication of interconnections between the economies of individual countries.

\subsection{Diversification under the conditions of globalization processes}

According to the study of the essence of diversification, its purpose is to increase the value of equity capital. This occurs when several companies merger and can achieve better results under the guidance of one parent company than if they acted alone. This diversification gives an opportunity to increase equity capital provided that the criteria of attractiveness, entry costs, and additional benefits are met.

The study established the existence of two main ways of diversification:

- diversification in related industries;

- diversification is non-core.

The basis for implementing the first mode of diversification is a strategic perspective. The merging of companies with strategic relevance leads to the emergence of additional competitive advantages, the use of which ultimately provides an opportunity to increase the value of equity. Areas of activity are strategically matched when their value chain offers the potential for:

1) the implementation of economies of scale or reduction of production costs associated with the sharing of technologies, production capacities, distribution network or brand;

2) the transfer of innovation (experience or technology);

3) additional differentiation.

The reason for the managerial decision to diversify into an unrelated industry is the fact that any company that has high returns and can be acquired on favourable terms deserves attention regardless of which industry it belongs to. That is, this kind of diversification takes place mainly for financial results, and not for compliance with a strategic match. The benefits of such diversification are as follows:

1) the distribution of risk between companies that are members of different industries;

2) the ability to quickly obtain a financial return (in the case when the company being acquired has a large potential of opportunities, 
including an appropriate management system, or needs the support of a stronger company for the implementation of profitable projects);

3 ) it is theoretically assumed that the third advantage of diversification in an unrelated industry is to reduce dependence on changing the phases of the cycle and obtaining greater financial stability.

However, the achievement of these three benefits leads to the need for constant attention of corporate governance to the management of the company in order to avoid possible negative consequences of non-core diversification.

The number of companies in the conglomerate and the level of their diversification necessitate a significant amount of information provision of corporate governance and each company with the aim of: determining the profitability of purchasing, selecting the most suitable managers for each company, obtaining sufficient knowledge about their strategic goals.

If the top management of the corporation lacks exceptional management capabilities, non-core diversification of companies belonging to different industries may be less successful compared to diversification in related industries.

As a result of the aforementioned diversification, the objective of corporate management is managing the economic portfolio of companies, which are a part of the corporation, with the maximum possible prediction of the prospects for their development.

According to the results of the study, six strategic approaches have been identified which contribute to the improvement of the diversified company's activities:

1) to purchase new companies;

2) to get rid of enterprises whose performance has appeared to be unsuitable for certain purposes or those that do not have long-term development prospects;

3 ) to restructure the economic portfolio if the results of the enterprise activity are low and growth prospects are not monitored;

4) switch to diversification on a different basis;

5) use multinational diversification;

6) get rid of unprofitable enterprises with potentially low activity.

The main way to get rid of an unattractive or non-profit business is to sell it. Sometimes such enterprises are transformed into financially independent companies, in which the parent company may retain a part of the shareholding. 
Corporate strategy for restoring, saving, and restructuring the portfolio is used when corporate management has decided: to make efforts to "cure the sick business portfolio." Low performance of companies may be caused by large losses in one or more industries, which affects the activities of the entire corporation, the presence of too many enterprises in unsustainable industries, the growth of non-payment companies, the acquisition of enterprises that did not meet the original expectations.

The corporate strategy of recovery aims to increase the profitability of loss-making enterprises.

The corporate strategy of saving involves reducing the number of enterprises entering the corporation. In this situation, the subject of sale is small companies that do not make a tangible contribution to the activities of the corporation, as well as those that do not meet the criteria stipulated by corporate governance, as the most significant for the further development of the corporation.

Under the restructuring strategy, we mean radical changes in the company's business portfolio, sales and purchases of companies to create a group of companies with high production rates.

Multinational diversification strategies include penetration into other sectors of the economy and different national markets. In spite of all the difficulties encountered in identifying and implementing such a large number of strategies (at least one for each industry, taking into account the specificities of national markets), multinational diversification creates significant competitive advantages for the company. Diversified multinational corporations can take advantage of the first type of diversification (economies of scale, experience transfer, and trademark sharing) to gain strong positions in several indigenous global industries. These advantages will subsequently enable a diversified multinational corporation to win competitive advantages for those companies engaged in business activity in just one industry in the national market, as well as in multinational corporations that operate in just one business. Companies that operate in one industry in the national market have only one source of profit - the consumer market of their country. An international company that deals with one type of activity may have sources of income from different countries, but they all depend on the situation in one industry. A diversified multinational corporation can use its advantage of low costs generated by economies of scale to lower its product prices until competitors' prices are lower than the cost of their 
products, thus gaining new market shares. But even without the advantage of low costs, a diversified transnational corporation can lower its products to win over competitors, and compensate for possible losses through profits gained from activities in other industries. A well-funded and effectively managed diversified transnational corporation can undermine the financial and competitive position of a company that operates in one industry in its national and/or global markets. Diversified multinational corporations can receive the most significant competitive advantage in those areas where significant economies of scale can be achieved, where there are obvious benefits to the common use of trademarks, as well as opportunities for technological exchange.

According to the results of the research and analysis of competitive strategies of transnational corporations in the context of the development of globalization processes, it has been established that globalization is the determining factor in the development of the world economy at the present stage, which is the growth of the interconnection and interdependence between the national economies of individual countries. The modern economic system is developing towards a global economy, in which goods, services, financial capital, people, information, knowledge, and ideas freely overcome the geographical boundaries of states. Under the influence of the aforementioned process, fundamentally new essences and phenomena in the global economy, such as the global market, the global company, global competition, etc., arise. The global economy is a fundamentally new way of managing the economy on a global scale, which is based on the subordination of both domestic and international economic processes to unified laws. The main economic entities of such an economy on a global scale are not the country, but transnational corporations - international by the nature of their activities of companies that own or control the production of products (or services) outside the country of origin, in different countries of the world, opening their branches there, which operate in accordance with the global strategy developed by the parent company.

At the current stage of economic development, decisions and strategies of multinational corporations are conditioned, firstly, by competition, and secondly, by market conditions. Based on the nature and extent of competition, as well as the conditions and dynamics of international markets, multinational corporations generally enjoy such competitive advantages as comparative advantages of individual countries, economies of scale, global business experience, economies of 
scale of logistics, marketing, procurement, as well as patented production technologies.

In a multinational environment, in contrast to the global one, dominate local (regional) traditions in consumption, especially consumer preferences and legal norms, characteristic of a particular country. Such an environment is characteristic, in particular, for the food and light industry, when the tastes and preferences of buyers largely affect their consumer choice and behaviour at the time of purchase. The multinational environment necessitates the use of an adaptive marketing strategy, in which the decentralization relationship should be the most optimal mechanism for interaction between the parent company and its affiliated subsidiaries.

Diversification of production in agriculture, unlike other sectors of the economy, has its own characteristics, due to the specifics of agricultural production. These features can be called objective preconditions for the application of diversification ${ }^{17}$. Taking into account the peculiarities of diversification are dictated, above all, by the diversity of soils in each, even a small farm. Properties of a specific soil are favourable for some crops and quite unfavourable for others, which are an objective basis for the cultivation of various crops, including fodder, as well as the development of the livestock sector.

Another feature of the application of diversification in the field of agriculture is the need for biologization of agriculture, which manifests itself in the alternation of crops in a rational, scientifically grounded system of crop rotation, which provides for the maximum supply of culture with nutrients. Thus, any farm has several types of raw materials of its own production (that is, relatively cheap). The above determines the formation of diversification projects in terms of creating their own processing. The incentive for the organization of processing, as well as its own product sales channels, is also a very large discrepancy in the prices of raw materials and finished products. Serving and processing enterprises are usually monopolists, which dictate their will to agricultural enterprises. This leads to the fact that agricultural commodity producers are forced to sell their products at low prices, and much of the profit remains in the sphere of processing and marketing.

\footnotetext{
17 Зоренко О. В. Деякі аспекти диверсифікації сільськогосподарських підприємств. Економіка: проблеми теорії і практики: зб. наук. пр. Вип. 204: в 5 т. Том IV. Дніпропетровськ : ДНУ, 2005. C. 1028-1034.
} 
The precondition for self-processing is the location of agricultural enterprises, their remoteness from the district and regional centres, and consequently, significant transportation costs. The conditions for own processing provide an opportunity not only to realize the finished products among the local population but also to issue them for the salary of employees of the enterprise.

To the peculiarities of agriculture, which should be taken into account in the process of development of diversification projects, the seasonal use of labour can be referred. Periods of intense work alternate with relatively calm, which makes it possible to use workers at this time in other areas of diversified production, and thus increase the efficiency of labour resources utilization, the level of productivity, the income of the population. The possibility of manoeuvring by the directions of production gives the agricultural producers simple types of labour that do not require considerable time for special training of workers.

The seasonal nature of the production process in agriculture also leads to the fact that enterprises do not have enough material to start it. The implemented project of diversification of production will ensure the equal income of the enterprise, provide the opportunity to use as little as possible the borrowed banking capital, which in today's conditions is unavailable for many agrarians due to high rates of loans, disparities in prices for agricultural products and resources for its production.

The peculiarities of agriculture, which should be taken into account in the process of developing diversification projects, include instability associated with natural factors (natural conditions). Unfavourable weather conditions lead to highly specialized enterprises not only to losses but also to bankruptcy. This feature predetermines the need for management to combine the main activity with the spheres where the result of the activity does not depend on the climatic factor (for example, provision of transport services, construction works, repair of equipment, services to the population, etc.).

Projects of diversification in the field of agro-industrial production should include: expansion of the nomenclature and assortment, change of the type of products produced by the enterprise, development of new types of industries for improving the efficiency of the economy, obtaining economic benefits, preventing bankruptcy, taking into account the ecological state and social needs of the population. 


\section{CONCLUSIONS}

The modern world is developing towards a global economy in which goods, services, financial capital, people, information, knowledge, ideas freely overcome the geographical boundaries of states. The basis of globalization is the growth of the interdependence of national economies and their closer integration. Formation of the unity of the world in the process of globalization is the methodological basis for the interpretation of globalization. The global economy is a fundamentally new way of managing the economy on a global scale, which is based on the subordination of both domestic and international economic processes to unified laws. Globalization is an important source of new opportunities and the cause of many disadvantages and even conflicts within individual states, as well as between countries (regions).

The processes of globalization have an impact on all the aspects of social and economic life in all countries of the world. It is determined that the process of globalization is objective. It has been established that globalization opens up more opportunities for the development of the world and national economies but the pace of its spread is uneven. The process of integration into the world economy is carried out by individual states more quickly. The mentioned provides them with higher rates of growth of the national economy, in particular, due to the diversification of activities of companies and corporate associations of the international level. Improving living standards in these countries creates additional opportunities for the development of democracy and the resolution of issues related to economic security. Enterprises define their areas of activity, focusing on key business areas that are in line with the state of development of globalization processes. The reason for the managerial decision to diversify into an unrelated industry implies that the company is highly profitable and can be acquired on advantageous terms, regardless of the industry it belongs to. Diversification of the industry should take into account its specifics, as well as specifics of activities of its companies and corporate formations.

\section{SUMMARY}

The article deals with the actual problems of globalization. The questions of the influence of processes of globalization on diversification of activity of companies and corporate associations are covered. Economic "globalization" is a historical process, which is the result of innovation in society and technological progress. The author 
presents the results of the analysis of global trends in the development of the world economy in conditions of globalization, internationalization, transnationalization, and regionalization. The available approaches of well-known economists to the definition of globalization are explored. The results of the analysis of problem aspects and positive effects of globalization and integration processes on the Ukrainian economy are highlighted. The possibilities of corporate associations that are created by the results of globalization processes are revealed. The main features of diversification of activities by sectors of the economy are presented; in particular, such features are highlighted for agriculture.

\section{REFERENCES}

1. Думная Н. Глобальная экономика - новая среда международного бизнеса. Интернащионализация и глобализация на бизнеса. Свищов, 1998. С. 2-16.

2. Некипелов А. Обзор: Глобализация как вызов национальным экономикам. Понятие глобализации. Свободная мысль. 1999. № 1. C. 117.

3. Осадчая И. Глобализация и государство: новое в регулировании экономики развитых стран. МЭиМО. 2002. № 11. C. 3-14.

4. Глобалізація / Економічна енциклопедія: У трьох томах. Т.1. Київ : Видавничий центр «Академія». 2000. С. 264-265.

5. Кочетов Э. Геоэкономика. Москва : БЕК. 1999. 480 с.

6. Моисеев С. Михайленко К. Terra Incognita: глобализация финансовых рынков. Вопросы экономики. 1999. № 6. С. 123-135.

7. Что требует осмысления в процессе глобализации. Резюме выступления президента Чехии Вацлава Гавела, а также результаты обсуждения, состоявшегося на конференции в Университете штата Мичиган. Трансформащия. 2000. Август-сентябрь. С. 4.

8. Anderson W. All Connected Now. Life in the First Global Civilization. N.Y.: Westview Press. 2001. 320 p.

9. World Economic Outlook. Wash. (D.C.): IMF. 1997. P. 44-48.

10. Глобалізація економічних процесів. Світова економіка: Підручник / А. С. Філіпенко, О. І. Рогач, О. І. Шнирков та ін. Київ : Либідь, 2000. С. 51-66.

11. Stiglits J. Globalization and Its Discontents. N.Y.: W.W. Norton $\&$ Co, 2002. 300 p.

12. Гіл Ч. Міжнародний бізнес. Київ : Основи, 2001. 854 с. 
13. Колодко Гж. Глобалізація i перспективи розвитку постсоціалістичних країн. Київ : Основні цінності, 2002. 248 с.

14. Герст П., Томсон Г. Сумніви в глобалізації. Пер. 3 англ. Київ : К.І.С., 2002. 306 с.

15. Ворошилова Г.О. Концептуальні засади дослідження глобалізації та іiі впливу на розвиток світового ринку послуг. Глобальні та національні проблеми економіки. 2017. № 16. С. 3842. URL: http://global-national.in.ua/archive/16-2017/16_2017.pdf.

16. Ботвіна Н. О. Вплив глобалізаційних та інтеграційних процесів на економічну безпеку України. Економічний аналіз: зб. наук. праць. Тернопіль : Видавничо-поліграфічний центр ТНЕУ «Економічна думка», 2014. Том 16. № 1. С. 28-33. URL: https//www.econa.org.ua/index/econa/article/.../pdf_35.

17. Зоренко О. В. Деякі аспекти диверсифікації сільськогосподарських підприємств. Економіка: проблеми теорії $i$ практики: зб. наук. пр. Вип. 204: в 5 т. Том IV. Дніпропетровськ : ДНУ, 2005. С. 1028-1034.

\section{Information about the author:} Korinko M. D.

Doctor of Economics, Professor, Head of Department of Audit and Entrepreneurship, National Academy of Statistics, Accounting and Audit, Ukraine 